\title{
Corporate Social Responsibility: Costs and Revenue
}

\author{
Diyah Santi Hariyani ${ }^{*}{ }^{*}$, Titik Purwati ${ }^{2}$, Wasito Wasito ${ }^{3}$, Nanik Ermawati ${ }^{4}$, \\ Maratul Azizah ${ }^{5}$
}

\author{
${ }^{1,5}$ Universitas PGRI Madiun \\ ${ }^{2}$ IKIP Budi Utomo Malang \\ ${ }^{3}$ STIE Muhammadiyah Tuban \\ ${ }^{4}$ Universitas Muria Kudus \\ *Diyah Santi Hariyani, Email: diyah.santi@unipma.ac.id
}

\begin{abstract}
The purpose of this research is to find out if the cost for Partnership and Community Development Program (known as PKBL in Indonesian abbreviation) as the implementation of Corporate Social Responsibility (CSR) activities on stateowned enterprises' revenue. The object of this research is the SOEs Banking sector Listed on the Indonesia Stock Exchange during 2015-2020. The method used in this study is qualitative descriptive, by taking secondary data, then analyzed the percentage of costs to its revenue. The results showed that CSR programs have an impact on the company's revenue. The increase in expenses can increase stakeholders' trust; the rise in revenue will also affect the company's value.
\end{abstract}

Keywords: Cost, Corporate Social Responsibility, Revenue, PKBL

\section{INTRODUCTION}

State-Owned Enterprises are one of the pillars of economic activity and other economic actors such as private and cooperatives that encourage economic growth. Business activities conducted by SOEs spread in various sectors of the economy ranging from the primary sector to the tertiary sector in the national economy. One of the business activities undertaken by state-owned enterprises in the service sector is banking. The presence of SOEs in the banking sector is characterized by the existence of state-owned banks (Government Banks) of PT Bank Negara Indonesia (Persero) Tbk (BBNI). PT Bank Rakyat Indonesia (persero) Tbk (BBRI). PT Bank Tabungan Negara (persero) Tbk (BBTN). PT Bank Mandiri (persero) Tbk (BMRI). Banking companies are the only companies that get guarantees from the government for their business activities. In banking regulations, not only are the products and services offered by banks regulated, but the bank institutions themselves are also strictly regulated. Such strict regulations need to be drawn up, given the failure of banks can have a long and profound impact on the economy [1]. Referring to article 74 of Law No. 40 of 2007, banking companies are one type of company that is not obliged to conduct CSR programs in connection with the activities of banking companies that are not directly related to natural resources.

According to [2], banking is one of the economic milestones in Indonesia. Banks are required to carry out their duties in the banking sector and provide evidence of concern for the community directly related to its operations. One form of such concern is CSR programs. Many benefits obtained by banks with the implementation of corporate social responsibility, namely banking products offered increasingly in demand by the public and companies favored by investors. In addition, CSR can be used as a marketing tool for a new model for the company if implemented on a long-term or sustainable basis. The implementation of CSR activities means that the company has to spend a certain amount of money. The cost will eventually become a burden that the company must bear to reduce revenue and result in the company's profit level will decrease. However, the good side by carrying out CSR activities of the company's image will be better in the eyes of the public that will have an impact on increasing public loyalty to the company, so that CSR can increase the value of the company[3]-[7]

Based on the above, it is proven that there is a relationship between CSR practices and the company's strategy in improving profitability. Implementing CSR 
practices indirectly becomes one of the promotional activities conducted by the company to the community and investors. The company will attract the hearts of the public and investors with activities responsibility to the environment. In addition, the company's CSR activities can be recognized as a long-term investment of the company in developing banking products. But there are still many companies that do not want to carry out CSR activities because they consider that CSR activities require large funds to reduce the profit earned by the company. Research found that CSR does not affect the company's value [8], [9]. While [10] found that CSR negatively affects the company's value.

The issue of the social responsibility of banking companies to the social environment is still widely highlighted. This research aims to analyze the costs of CSR disclosure on revenue at SOEs Banking companies Listed on the Indonesia Stock Exchange in 2015-2020. Especially in 2020, during the covid-19 virus pandemic, it takes many parties to channel financial assistance. CSR in 2020 will be more focused on handling environmental development so that the large CSR costs can cause burdens and losses for the company.

\section{LITERATURE REVIEW}

\subsection{Stakeholders Theory}

Theory of stakeholders [11] emphasis on organizational accountability far exceeds simple financial or economic performance. This theory states that organizations will voluntarily disclose information about their environmental, social, and intellectual performance, beyond and above its mandatory request to meet real expectations or recognized by stakeholders. One form of voluntary disclosure that is overgrowing today is CSR publications. Through social and environmental disclosure, companies can provide more sufficient and complete information related to activities and their influence on the social conditions of society and the environment [12]. CSR benefits companies to open a wider market share that improves relations with stakeholders and regulators and obtains permission to operate on a social basis.

\subsection{Corporate Social Responsibility}

Corporate Social Responsibility is a strategic policy program of a company or organization as a form of social care. Article 74 of Law No. 40 of 2007 concerning Limited Liability Companies regulates Social and environmental responsibility. The company that carries out its business activities in the field related to natural resources is obliged to carry out its social and environmental responsibilities.

Government Regulation No. 47 of 2012 on Social and Environmental Responsibility of Limited Liability
Companies has several rule points closely related to the implementation of Sustainable Finance in Indonesia contained in articles 2 and 3. Initially, the PKBL was regulated in the ministerial meeting number 236/MBU/2003 and then replaced on April 27, 2007 with the ministerial meeting number PER-05/MBU/2007 concerning the PKBL SOEs. Without questioning the type and field of business, all SOEs are obliged to carry out corporate social responsibility.

CSR implementation in SOEs is more often called PKBL is a partnership relationship between SOEs and small businesses to improve the ability of small businesses to become better and independent with the help of loans. The loan will be given to people who need funds to develop the business. Community Development Program is a program that aims to empower the community by seeking the welfare of the community with its social programs.

[10] provide a statement that corporate value is reflected in financial conditions only. Still, the company must also rely on the triple bottom line that is responsible for the social aspect. The concept of the triple bottom line or 3P (profit, people, planet) into a major breakthrough in the world of CSR [13] . So to realize the company's goal to grow sustainably, it is necessary to align the achievement of profit performance with social performance (people) and environmental performance (planet) on an ongoing basis.

\section{RESEARCH METHODS}

This research is qualitative descriptive research, to solve problems related to the impact and benefits of CSR disclosure for SOEs Banking Sector Listed on the Indonesia Stock Exchange in 2015-2019. Source data from the annual report and Sustainability Reporting through the company's official website and www.bei.co.id. Data collection techniques with research stages include activities related to CSR in the StateOwned Banking sector, calculating the amount of PKBL costs and revenue obtained by the company.

\section{RESULTS AND DISCUSSION}

The results of data processing can be seen in table 1 , table 2 , table 3 , and table 4 below:

Table 1 shows that CSR activities conducted by BBNI were able to increase the percentage of revenue each year even though in 2016 it had decreased to $0.20 \%$. CSR program conducted by BBNI in the form of BNI sharing. BNI go Green. Kampoeng BNI. Tahun 2019 BNI distributed Rp116,45 billion as a partnership fund for 2,246 partners. One of the flagship programs is the One Village One Product (OVOP) cluster in the form of MSME credit expansion, expected to run massively to become the engine of national economic growth. The 
purpose of CSR energy is one form of BNI's social performance and investment in the community. Through the implementation of a planned, targeted, transparent and sustainable CSR program, BNI wants to create benefits for the company's presence through efforts to increase concern for the community and the environment.

Table 2 shows that BBRI CSR activities can increase the percentage of revenue each year, although, in 2020, it decreased to $0.35 \%$. In 2020, the BRI Peduli CSR program and "BRILian Fight Covid-19" distributed various assistance in handling Covid-19 in Indonesia with a total value of $\mathrm{Rp} 106.9$ billion. A restructuring Table 1. Comparison of BBNI CSR Funds in 2015-2020 policy program from the government for citizens has the effect of causing a decrease in revenue. Partnership Program as CSR implementation in the form of disbursement of funds in loans to finance working capital and additional loans for partner businesses. Environmental development programs in distributing funds for victims of natural disasters, education and training, health improvement, development of infrastructure facilities, worship facilities, poverty alleviation.

\begin{tabular}{|l|r|r|r|}
\hline \multicolumn{1}{|c|}{ Year } & \multicolumn{1}{|c|}{ PKBL Cost } & \multicolumn{1}{c|}{ Revenue } & \multicolumn{2}{c|}{ Comparison With Revenue } \\
\hline 2015 & 101 & 36.895 & $0,27 \%$ \\
\hline 2016 & 88 & 43.768 & $0,20 \%$ \\
\hline 2017 & 196 & 48.178 & $0,41 \%$ \\
\hline 2018 & 219 & 54.139 & $0,41 \%$ \\
\hline 2019 & 275 & 58.532 & $0,47 \%$ \\
\hline 2020 & 291 & 56.173 & $0,52 \%$ \\
\hline
\end{tabular}

Source: Data Processed 2021

Table 2. Comparison of BBRI CSR Funds in 2015-2020

\begin{tabular}{|l|r|r|r|}
\hline \multicolumn{1}{|c|}{ Year } & \multicolumn{1}{|c|}{ PKBL Cost } & \multicolumn{1}{|c|}{ Revenue } & \multicolumn{2}{c|}{ Comparison With Revenue } \\
\hline 2015 & 181 & 85.434 & $0,21 \%$ \\
\hline 2016 & 222 & 94.788 & $0,23 \%$ \\
\hline 2017 & 360 & 102.912 & $0,35 \%$ \\
\hline 2018 & 508 & 111.583 & $0,46 \%$ \\
\hline 2019 & 559 & 121.756 & $0,46 \%$ \\
\hline 2020 & 413 & 116.932 & $0,35 \%$ \\
\hline
\end{tabular}

Source: Data Processed 2021

Table 3 shows that CSR activities conducted by BBTN despite having a lower percentage value than other banks but in 2020 were able to provide an increase in revenue percentage reached $0.20 \%$. The partnership development fund realized in 2020 amounted to $\mathrm{Rp}$ $30,960,000$, and the allocation fund for environmental development programs (worship facilities, education training, poverty alleviation, public infrastructure, natural resources, health improvement and nature conservation) amounted to Rp. 8,357 billion. The implementation of PKBL management policy on the impact of the covid 19 pandemics was carried out by restructuring as many as 30 debtors with principal balances of Rp. 664,722 million. 
Table 3. Comparison of BBTN CSR Funds in 2015-2020

\begin{tabular}{|c|r|r|r|}
\hline Year & PKBL Cost & \multicolumn{1}{|c|}{ Revenue } & Comparison With Revenue \\
\hline 2015 & 11 & 6.811 & $0,16 \%$ \\
\hline 2016 & 4 & 8.164 & $0,05 \%$ \\
\hline 2017 & 5 & 9.341 & $0.06 \%$ \\
\hline 2018 & 5 & 10.089 & $0,05 \%$ \\
\hline 2019 & 7 & 8.962 & $0,08 \%$ \\
\hline 2020 & 18 & 8.914 & $0,20 \%$ \\
\hline
\end{tabular}

Source: Data Processed 2021

In table 4 shows the cost of CSR activities conducted by BMRI and revenue each year fluctuating. BMRI still recorded a positive performance during 2020, despite the decline compared to 2019. BMRI was able to maintain a percentage of revenue above $0.20 \%$ for 4 consecutive years. BMRI CSR program forms in the form of independent young entrepreneurs, SOEs creative houses, village economic centers, coding mum (empowerment of Indonesian migrant workers through programming language training), vocational (improving skills and skills), community development (helping social, educational and environmental problems as well as the development of facilities and infrastructure)

Table 4. Comparison of BMRI CSR funds in 2015-2020

\begin{tabular}{|l|r|r|r|}
\hline \multicolumn{1}{|c|}{ Year } & \multicolumn{1}{|c|}{ PKBL Cost } & \multicolumn{1}{c|}{ Revenue } & \multicolumn{2}{c|}{ Comparison With Revenue } \\
\hline 2015 & 40 & 45.363 & $0,09 \%$ \\
\hline 2016 & 80 & 51.825 & $0,15 \%$ \\
\hline 2017 & 118 & 51.988 & $0,23 \%$ \\
\hline 2018 & 115 & 54.623 & $0,21 \%$ \\
\hline 2019 & 148 & 59.440 & $0,25 \%$ \\
\hline 2020 & 134 & 56.508 & $0,24 \%$ \\
\hline
\end{tabular}

Source: Data Processed 2021

The percentage of costs and revenue of SOEs in the banking sector listed in idx in 2015-2020 can be seen in figure 1 below:

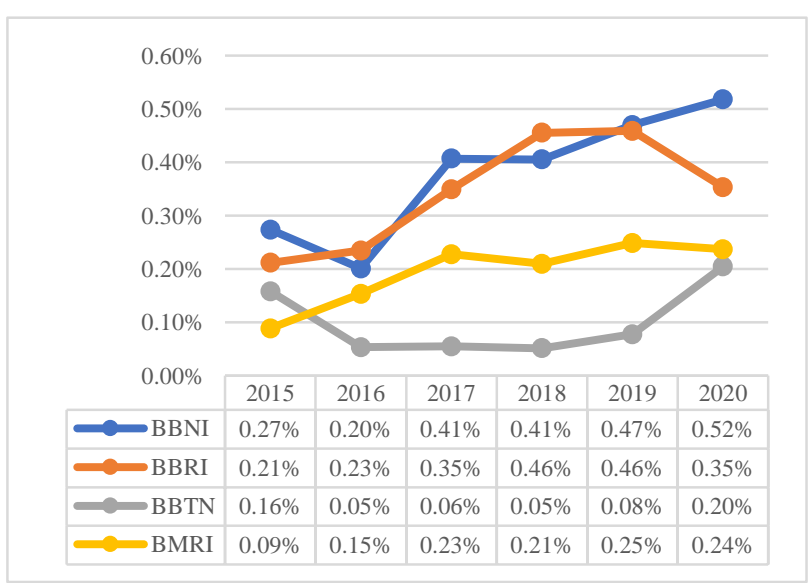

Source: Data processed: 2021

Figure 1. Research Percentage Output Results

Figure 1 shows that the output results for all stateowned banking sectors listed in IDX in 2015-2019 have a positive value. In 2020 during the covid-19 pandemic that impacted the economy globally, it was proven that the state-owned banking sector in Indonesia could maintain its stability. CSR activities that incur costs can have a positive impact on banking performance. Based on the percentage of CSR revenue comparison that shows positive value, the increase in CSR costs can increase public trust. Based on stakeholder theory, the company has one of the responsibilities to stakeholders: making social disclosure. CSR activities conducted and expressed continuously in the annual report will impact the company's survival and get support from stakeholders [14]. The company is not an entity that only operates for its benefit, but must provide benefits to its stakeholders [15]. The costs incurred for CSR programs are already effective and can offer sustainability benefits to the company in the short and long term.

This research is in line with the results [16] that the costs and benefits of CSR programs are already running effectively in mining sector companies in 2016-2018. The increase of the expenses increases public confidence, especially in preserving the environment, improving 
people's standard of living through educational programs. [17] CSR has a positive effect on financial performance because it can create a reputation for competitive ability through customer satisfaction. This research also supports previous research that with CSR disclosure positively affects the financial performance of banking companies projected by indicators ROA, ROE, CAR, both state-owned and private banking status [18]. The study results [19] found that CSR positively influenced financial performance in the KEJI Index. CSR can improve the company's profit value, business structure, performance, and prospects in Pakistan. Research conducted in Montenegro country, Croatia, Slovenia shows that negara-countries with higher CSR levels will improve the company's reputation [20]. CSR has a positive influence on the company's value [3], [4], [6]

\section{CONCLUSION}

Based on the discussion, it can be concluded that the percentage of cost comparison with positive revenue indicates that PKBL as CSR implementation has benefits for banking companies. However, the percentage of value is low due to many other variables that provide more benefits for the company's value such as company growth, investment decisions, company size, good financial governance, leverage, capital structure, and so on. Cost comparison to CSR revenue has been effective and can be improved again by paying attention to the surrounding community's needs. To banking is expected CSR is not only limited to the fulfillment of the rule of law alone, but can also be used as a long-term sustainability investment. CSR can be an advertisement for the company's products and can expand cooperation with local governments, customers, and the community.

\section{REFERENCES}

[1] Taswan, Manajemen Perbankan: Konsep, Teknik dan Aplikasi. Yogyakarta: UPP STIM YKPN., 2006.

[2] A. Pratiwi, N. Nurulrahmatia, and P. Muniarty, "Pengaruh Corporate Social Responsibility (CSR) Terhadap Profitabilitas Pada Perusahaan Perbankan Yang Terdaftar di BEI," Owner, Ris. J. Akunt., vol. 4, no. 1, p. 95, 2020, doi: 10.33395/owner.v4i1.201.

[3] A. D'Amato and C. Falivena, "Corporate Social Responsibility and Firm Value: Do Firm Size and Age Matter? Empirical Evidence from European Listed Companies," Corp. Soc. Responsib. Environ. Manag., vol. 27, no. 2, pp. 909-924, 2020, doi: 10.1002/csr.1855.

[4] J. Fiona, K. Ritonga, and Rusli, "Pengaruh Corporate Social Responsibility Disclosure
Terhadap Firm Value Dimoderasi Oleh Good Corporate Governance," JOM Fekon, vol. 4, no. 1, pp. 1570-1582, 2017.

[5] J. Seok, Y. Lee, and B. Do Kim, "Impact of CSR News Reports on Firm Value," Asia Pacific J. Mark. Logist., vol. 32, no. 3, pp. 644-663, 2019, doi: 10.1108/APJML-06-2019-0352.

[6] H. Servaes and A. Tamayo, "The Impact of Corporate Social Responsibility on Firm Value: The Role of Customer Awareness," Manage. Sci., vol. 59, no. 5, pp. 1045-1061, 2013, doi: 10.1287/mnsc. 1120.1630 .

[7] H. Zhou et al., "Who Benefits from Mandatory CSR? Evidence from the Indian Companies Act 2013," Emerg. Mark. Rev., 2020, [Online]. Available:

https://doi.org/10.1016/j.matdes.2020.108947.

[8] D. S. Hariyani, T. Ratnawati, and N. Rahmiyati, "The Relationship Between Company Value and Good Financial Governance: Empirical Evidence from Indonesia," J. Asian Financ. Econ. Busines, vol. 8, no. 7, pp. 447-456, 2021, doi: 10.13106/jafeb.2021.vol8.no7.0447.

[9] Soedjatmiko, B. Tjahjadi, and N. Soewarno, "Do Environmental Performance and Environmental Management Have a Direct Effect on Firm Value?," J. Asian Financ. Econ. Bus., vol. 8, no. 1, pp. 687-696, 2021, doi: 10.13106/jafeb.2021.vol8.no1.687.

[10] B. S. Baroma, "The Impact of Corporate Social Responsibility on Firm Value and Financial Performance: An Empirical Study on Companies Listed in Egyptian Stock Exchange," Alexandria J. Account. Res., vol. 1, no. 2, 2017.

[11] R. Gray, R. Kouhy, and S. Lavers, "Corporate Social And Environmental Reporting A Review Of The Literature And A Longitudinal Study Of UK Disclosure," Accounting, Audit. Account. J., vol. 8, no. 2, pp. 47-77, 1995, doi: $10.1108 / 09513579510146996$.

[12] I. Ghozali and A. Chariri, Teori Akuntansi. Semarang: Badan Penerbit Universitas Diponegoro, Semarang, 2007.

[13] J. Elkington, The Triple Bottom Line in 21st Century Business. Gabriola Island, 1998.

[14] R. Albuquerque, Y. Koskinen, and C. Zhang, "Corporate social responsibility and firm risk: Theory and empirical evidence," Manage. Sci., vol. 65, no. 10, pp. 4451-4469, Oct. 2019, doi: $10.1287 / \mathrm{mnsc} .2018 .3043$. 
[15] P. Crifo, E. Escrig-Olmedo, and N. Mottis, "Corporate Governance as a Key Driver of Corporate Sustainability in France: The Role of Board Members and Investor Relations," J. Bus. Ethics, vol. 159, no. 4, pp. 1127-1146, 2019, doi: 10.1007/s10551-018-3866-6.

[16] L. Lusy and V. Devina, "Analisa Cost and Benefit atas Sustainability Reporting," JAD J. Ris. Akunt. dan Keuang. Dewantara, vol. 4, no. 2, pp. 85-94, 2021, [Online]. Available: http://ejournal.stiedewantara.ac.id/index.php/JA D/article/view/764.

[17] S. P. Saeidi, S. Sofian, P. Saeidi, S. P. Saeidi, and S. A. Saaeidi, "How Does Corporate Social Responsibility Contribute To Firm Financial Performance? The Mediating Role Of Competitive Advantage, Reputation, And Customer Satisfaction,” J. Bus. Res., pp. 341350, 2014, doi: 10.1016/j.jbusres.2014.06.024.

[18] K. O. Julialevi and W. Ramadhanti, "Pengaruh Pengungkapan Corporate Social Responsibility Terhadap Kinerja Keuangan Perbankan Indonesia (Studi Komparatif Perbankan BUMN dan Swasta)," J. Pendidik. dan Teknol. Indones., vol. 1, no. 2, pp. 91-95, 2021, doi: 10.52436/1.jpti.19.

[19] W. Oh and S. Park, "The Relationship Between Corporate Social Responsibility And Corporate Financial Performance In Korea," Emerg. Mark. Financ. Trade, vol. 51, no. September, pp. 8594, 2015, doi: 10.1080/1540496X.2015.1039903.

[20] J. Lu, L. Ren, C. Zhang, J. Qiao, M. Kovacova, and J. Streimikis, "Assessment of Corporate Social Responsibility and its Impacts on Corporate Reputation of Companies in Selected Balkan Countries Former Yugoslavia States," Technol. Econ. Dev. Econ., vol. 26, no. 2, pp. 504-524, 2020, doi: 10.3846/tede.2020.12069. 